\title{
シンポジウム記録 水産資源の有効利用とゼロエミッション
}

\section{III-4. 貝殼一ホタテ貝殼パウダーと セルロース繊維樹脂の機能性複合材料の開発}

岡部敏弘

青森県産業技術センター弘前地域研究所

III-4. Shell-Application to plastics

TOSHIHIRO OKABE

Aomori Prefectural Industrial Technology Research Center, Hirosaki, Aomori 036-8363, Japan

地球温暖化による自然㷋害が注目されているなかで, $\mathrm{CO}_{2}$ 削減が大きな数值目標となっている。また，本案 件で取り上げている PP 樹脂（プラスチック製品）はあ らゆるところで使用されて抢り，廃プラスチックの処理 （埋め立て地の限界・焼却による $\mathrm{CO}_{2}$ 排出等）について は大きな社会問題となっている。

これに対して著者らは, 脱石油製品（脱プラスチック 化）及び， $\mathrm{CO}_{2}$ 削減をテーマに，青森県産資源である ホタテ貝殼を用いたバイオマス強化樹脂の開発に取り組 み，新たな資源循環型 $\mathrm{ECO}$ 材料及び製品を提供するこ とを目的として，本研究を実施した。

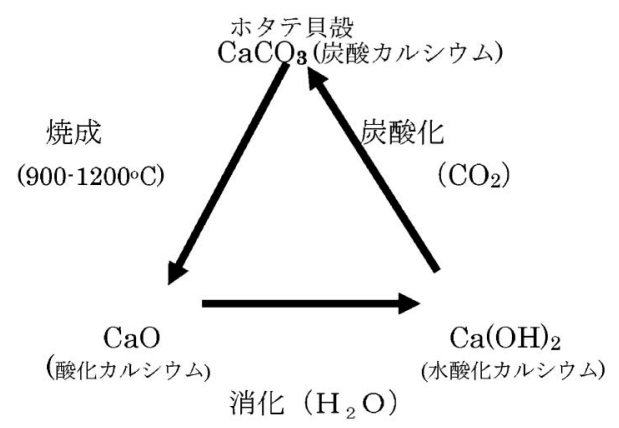

図 1 貝殼成分の可逆的化学変化
ホタテ貝殼は図 1 に示す様に, 焼成 $\rightarrow$ 消化 $\rightarrow$ 炭酸化 の循環型材料であることが最大の特長である。主な構造 として, 幅数 $\mu \mathrm{m}$ 程度の短冊状の炭酸カルシウムの結晶 が規則正しく配列しているので，粉砕すると炭酸カルシ ウムの結晶形状により, 棒状の粉体が得られる。したが って本粉体をプラスチックと複合化すると，一般に用い られている繊維強化材等と同様に機械的物性を向上させ ることができると考えられる。ただし，ホタテ貝殼粉体 を $40 \mathrm{wt} \%$ 以上混練した場合, 機械的物性（引張強度） が低下することが確認できており，図 2 に示すよう に，セルロース緘維を混練させることで，機械的強度 （引張強度及び，曲げ強度）を向上させることができた。 以上の結果からホタテ貝殼粉末とセルロース繊維のバイ オマス資源量としては，50\% 以上でも十分な強度を持 った PP 樹脂複合材料が開発できた。

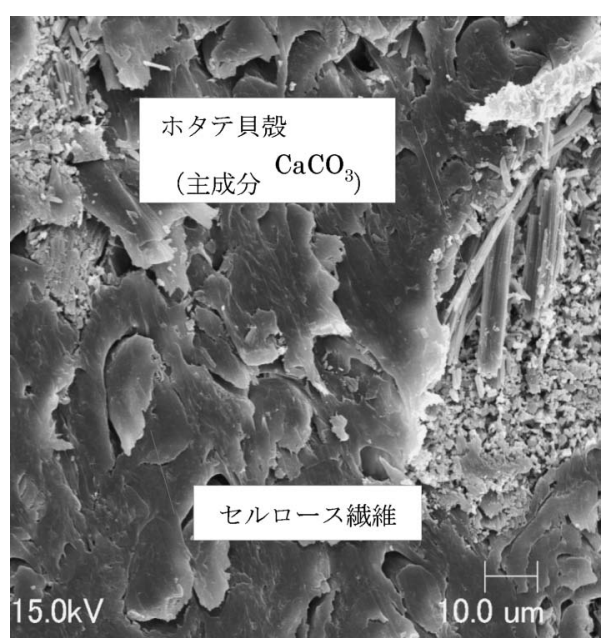

図 $2 \mathrm{PP}$ 樹脂とホタテ貝殼粉砕物とセルロース繊維の混 合物 SEM の断面写真 